\title{
Influence of nicotine on healing of vesical sutures in rabbits ${ }^{1}$
}

\author{
A influência da nicotina na cicatrização de suturas vesicais em coelhos
}

\author{
Christiano Machado², Eduardo Wei Kin Chin ${ }^{3}$, Sérgio Ossamu Ioshii ${ }^{4}$, Renato Tâmbara Filho ${ }^{5}$, Aline Von Bathen ${ }^{6}$ \\ 1. Research performed at Division of Urology, Santa Casa de Misericórdia of Curitiba (SCMC), Paraná, Brazil. \\ 2. MD, Master in Surgery, Federal University of Paraná (UFPR), Brazil. \\ 3. MD, Resident, Division of Urology, SCMC, Paraná, Brazil. \\ 4. Full Professor, Division of Pathology, Pontific Catholic University (PUC-PR). Associate Professor, Division of Pathology, UFPR, Paraná, Brazil. \\ 5. Associate Professor, Division of Urology, UFPR, Paraná, Brazil. \\ 6. Graduate Student, School of Medicine, PUC-PR, Paraná, Brazil.
}

\begin{abstract}
Purpose: To study the effects of nicotine on inflammatory cells, deposition of collagen and its interference on the strength of tissue in vesical sutures in rabbits. Methods: Twenty New Zealand rabbits were used, randomized into two groups: group $\mathrm{N}$, consisting of 10 animals, to which nicotine was administered in the dose of $2 \mathrm{mg} / \mathrm{kg}$ of weight as a subcutaneous injection, diluted in $1 \mathrm{ml}$ of saline solution at $0.9 \%$ in a daily administration during the 28 days prior to the surgery; and group $\mathrm{C}$, consisting of 10 animals, to which saline solution at $0.9 \%$ was administered in the same conditions and time intervals of the nicotine group. All the animals underwent cystotomy and suture of the bladder wall 28 days after the administration of nicotine or saline solution. The measurements were performed on the fourth and seventh day in each group after cystectomy and euthanasia of the animals. A fragment of bladder was removed and sent for a tensile strength test to evaluate the tissue strength and another fragment underwent a histological analysis of inflammatory process and deposition of collagen. Results: There was a decrease of neutrophils on the fourth postoperative day ( $p=0.079)$ and an increase of plasmocytes on the seventh postoperative day $(p=0.053)$ in the animals that were given nicotine, without statistical difference in relation to the control group. In the analysis of the proliferation of fibroblasts, deposition of collagen and tensile strength test, there was no statistical difference in relation to the control group. Conclusion: The administration of nicotine in rabbits did not influence the healing process of vesical suture in relation to the inflammatory cells, deposit of collagen and tissue strength of the suture.
\end{abstract}

Key words: Urinary Bladder. Collagen. Nicotine. Wound Healing. Suture Techniques. Rabbits.

\section{RESUMO}

Objetivo: Estudar os efeitos da nicotina sobre as células inflamatórias, deposição de colágeno e sua interferência sobre a força tecidual em suturas vesicais de coelhos. Métodos: Foram utilizados 20 coelhos Nova Zelândia, divididos de maneira aleatória em dois grupos: grupo N, composto de 10 animais, no qual foi administrada nicotina na dose de 2mg/ Kg de peso por via subcutânea, diluída em 1ml de solução fisiológica a 0,9\% em 1 aplicação diária por 28 dias prévios à cirurgia; e grupo C, composto por 10 animais, no qual foi administrada solução fisiológica a 0,9\% nas mesmas condições e intervalos de tempo do grupo nicotina. Todos os animais foram submetidos à cistotomia com sutura da parede vesical após 28 dias da administração de nicotina ou solução fisiológica. As aferições foram realizadas no $4^{\circ}$ e $7^{\circ}$ dia em cada grupo após cistectomia e eutanásia dos animais. Uma parte da bexiga foi submetida a teste de tração para avaliar a força tecidual da sutura e outro fragmento foi submetido à análise histológica de processo inflamatório e deposição de colágeno. Resultados: Houve uma diminuição de neutrófilos no $4^{\circ}$ dia pós-operatório $(p=0,079)$ e aumento de plasmócitos no $7^{\circ}$ dia após a cirurgia $(\mathrm{p}=0,053)$ nos animais que receberam nicotina, sem diferença estatística em relação ao grupo controle. Na análise de proliferação de fibroblastos, deposição de colágeno e teste de tração tecidual, não houve diferença estatística em relação ao grupo controle. Conclusão: A administração de nicotina em coelhos não influenciou no processo de cicatrização de sutura vesicais em relação às células inflamatórias, depósito de colágeno e força tecidual da sutura.

Descritores: Bexiga Urinária. Colágeno. Nicotina. Cicatrização de Feridas. Técnicas de Sutura. Coelhos. 


\section{Introduction}

Currently, smoking is one of the main problems of public health all over the world, due to its association with various illnesses. Among them, important for urology, the cancer of the bladder stands out as it is recognizably association with the habit of smoking. Furthermore, smoking may be directly related to the increase of prevalence of the lower urinary tract symptoms ${ }^{1}$. There are approximately five thousand components in the tobacco, among the most toxic ones it is nicotine, an odorless and colorless alkaloid substance that when inhaled or injected may liberate catecholamines and result in vasoconstriction with decrease of tissue perfusion ${ }^{2}$. After a tissue lesion the process of restoration of the integrity of the tissue is started by means of a series of cellular, physiological and biochemical events highly dynamic and integrated. Didactically, healing may be divided into three distinct phases: inflammation, proliferation and maturation or remodeling, which overlap in time and cannot be seen as a simple series of sequential steps $^{3,4}$. Among the various factors that may affect the healing of wounds, nicotine appears as one of the factors that may interfere negatively in the healing process, due to its effect of vasoconstriction $^{5}$. Although the effect of nicotine has been the object of scientific studies in relation to healing in various specialties such as dermatology, odontology and general surgery, studies related to the urinary tract have not been made yet $^{6-8}$. The objective of the present study is to evaluate the influence of nicotine in the healing process of vesical sutures in rabbits that have undergone cystotomy, by means of analyzing the histological alterations and the strength of tissue tension.

\section{Methods}

The experimental procedures were carried out at the Center of Surgical Research of the Post-Graduation Program in Clinical Surgery of the Federal University of Paraná, at the Medical Research Institute - IPEM and at the Technical Institute of Central Laboratory of Development an Research of Paraná - LACTEC and they were carried out according to the regulations of Brazilian College of Animals Experimentation - COBEA. Consent was obtained from the local ethics committee. In order to accomplish this experiment 20 male rabbits were used (Oryctolagus cuniculus), New Zealand, white, weighing from 2600 to $3750 \mathrm{~g}$, ages varying from 90 to 110 days. The animals were divided at random into two groups: Group N with 10 animals that were given nicotine and Group C with 10 animals that were given saline solution at $0.9 \%$; each group was divided in two subgroups, having five rabbits each. The subgroups were called, according to the time of postoperative evaluation (postoperative day 4 and 7), N4, N7, C4 and C7. The animals from group N were given nicotine (Nicotine di-tartrate salt, Sigma, Saint
Louis, Missouri, USA), for a period of 28 days prior to the surgical procedure, as a subcutaneous injection and in a dose of $2 \mathrm{mg}$ per kilogram of weight, once a day, diluted in saline solution at $0.9 \%$ to complete $1 \mathrm{ml}$. In Group C, the animals were given saline solution at $0.9 \%$, in the volume of $1 \mathrm{ml}$, once a day, as a subcutaneous injection for the same period of time as the nicotine group. All animals were housed under standard laboratory conditions, and they had free access to water and laboratory rabbit chow. After complete 28 days, the animals underwent surgical procedure. Associating xylasine and ketamine given as an intramuscular injection carried out anesthetic induction. After a laparotomy, the bladder was identified and externally mobilized and it was made a longitudinal incision on its wall in the dome region, followed by the closing of the cystotomy by means of a running suture, with 5-0 chromic catgut. After that, the bladder was put back in the abdominal cavity and the abdominal wall was closed. In the post-surgery period the administering of nicotine or saline solution was maintained for all the days until the completion of the four or seven days according to the subgroup of the animal. When the postoperative days were over for each group, the euthanasia of the animals was carried out. After anesthetic induction, the abdomen was entered through the same previous incision and a cystectomy was made through sectioning its base. The bladder was put in a jar filled with saline solution at $0.9 \%$ and then the rabbit was sacrificed by means of administering an intra-cardiac dose of fentanyl. Then the bladder was open, in a way as to let the suture remain in the central and transverse position in order to be submitted to the traction test. After that, a fragment of approximately $1 \mathrm{~cm}^{2}$ including suture area and adjacencies was removed and it was placed in formalin at $10 \%$ for histological analysis. The histological analysis was performed by the technique of hematoxylin and eosin in order to evaluate intensity of acute inflammatory infiltrated, intensity of chronic inflammatory, intensity of fibroblast proliferation. Mature and immature collagens were analyzed by picrosirius-red F3BA by means of microscopy technique with polarized light and computerized morphometric analysis. In the RGB system (red, green and blue) the values for black (background), for shades of red (collagen type I) and for shades of green (collagen type III) were taken into account. In the histological cuts that were analyzed the microscopic field was determined on the line of anastomosis, in 5 different fields, and then the arithmetic averages were obtained. The percentage of the occupied area was calculated based on the fibers that contained collagen types I and III. The vesical segment that was taken for the traction test measured approximately $15 \mathrm{~mm}$ in width and $5 \mathrm{~mm}$ in thickness, it was kept immersed in physiological serum at $0.9 \%$ and soon after that it was analyzed for the maximum strength of tissue tension prior to rupture, expressed in kgf, by a computerized traction machine. In order to prove the objectives raised in this study these tests were used, 
parametric tests "t de Student”, for independent samples and paired and the non-parametric "Mann-Whitney" and "Wilcoxon (paired dates)" through the software "Primer of Biostatistics". The level of significance adopted was less than $5 \%(\mathrm{p}<0.05)$.

\section{Results}

In the comparison among the groups, taking into account the inflammatory cells and the proliferation of fibroblasts, it was not observed any significant difference in any of the analyzed moments (Figures 1 and 2). However, it is important to emphasize that on the day four the number of neutrophils was smaller in the Nicotine group $(p=0.079)$ (Figure 3) and on the day seven the number of plasmocytes was larger in the Nicotine group $(p=0.053)$. In the comparisons among the groups, about the values of collagen I and III, it was not observed any statistical difference in any of the analyzed moments (Figures 4 and 5). In the comparison among the groups taking the traction test, it was not observed any significant difference in any of the analyzed moments (Table 1). Concerning the analysis intra-group (the same group in different moments) it was observed that the saline solution group presented larger resistance during traction test on the day seven $(\mathrm{p}=0.028)$. In the Nicotine group, it was not observed any significant difference (Figure 6).

TABLE 1 - Descriptive Statistic of Traction test in the study groups

\begin{tabular}{|c|c|c|c|c|c|c|}
\hline DATA & MEAN & $\begin{array}{l}\text { STANDARD } \\
\text { DEVIATION }\end{array}$ & MINIMUM & MAXIMUM & MEDIAN & P VALUE \\
\hline \multicolumn{7}{|c|}{ DIFFERENT GROUPS } \\
\hline - 4th Day & 0,262 & 0,103 & 0,106 & 0,476 & 0,240 & 0,483 \\
\hline - Saline Solution & 0,237 & 0,097 & 0,106 & 0,355 & 0,223 & \\
\hline - Nicotine & 0,287 & 0,114 & 0,187 & 0,476 & 0,256 & \\
\hline • 7th Day & 0,433 & 0,115 & 0,283 & 0,637 & - & 0,958 \\
\hline - Saline Solution & 0,435 & 0,064 & 0,332 & 0,503 & - & \\
\hline - Nicotine & 0,431 & 0,160 & 0,283 & 0,637 & 0,388 & \\
\hline \multicolumn{7}{|l|}{ SAME GROUPS } \\
\hline - Saline Solution & & & & & & 0,028 \\
\hline • 4th Day & 0,237 & 0,097 & 0,106 & 0,355 & 0,223 & \\
\hline • 7th Day & 0,435 & 0,064 & 0,332 & 0,503 & - & \\
\hline - Nicotine & & & & & & 0,150 \\
\hline - 4th Day & 0,287 & 0,114 & 0,187 & 0,476 & 0,256 & \\
\hline - 7th Day & 0,431 & 0,160 & 0,283 & 0,637 & 0,388 & \\
\hline
\end{tabular}

NOTE: The number of animals in each group is five.

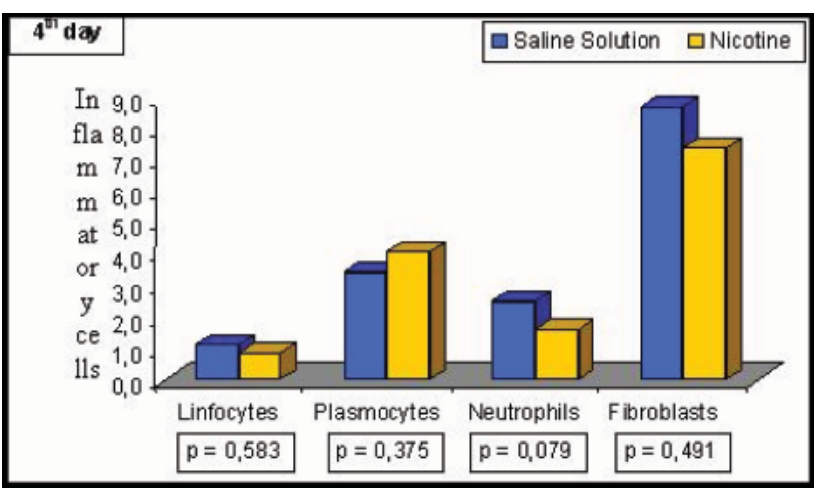

FIGURE 1 - Inflammatory cells and fibroblasts, in the study groups - 4th day

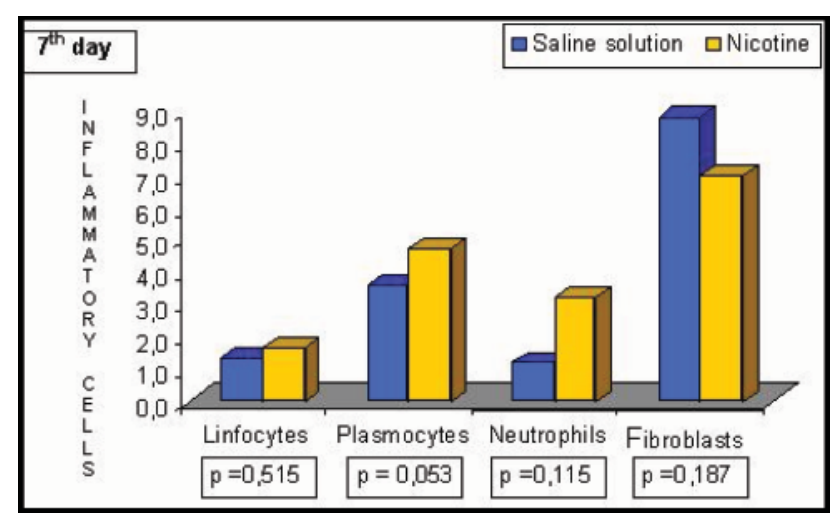

FIGURE 2 - Inflammatory cells and fibroblasts, in the study groups -7 th day 


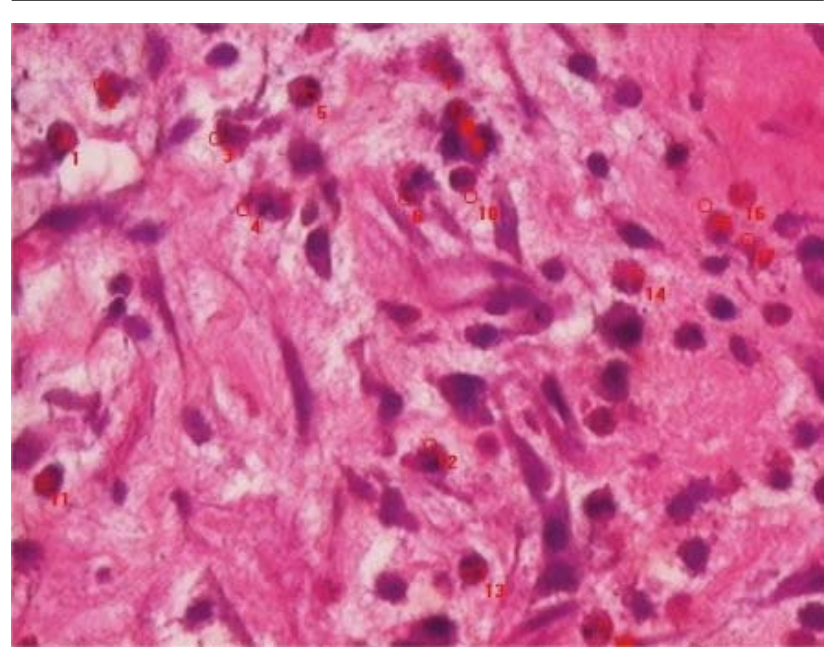

FIGURE 3 - Neutrophils count in 4th day (nicotine group). Hematoxylin-eosin technique

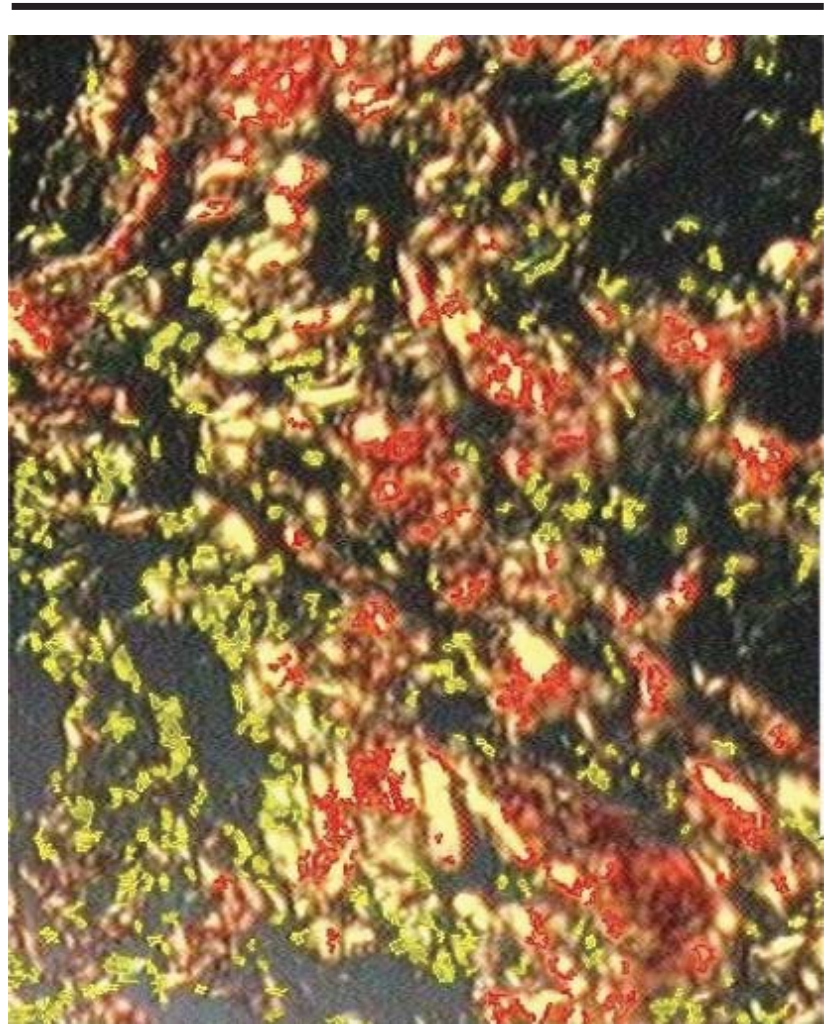

FIGURE 5 - Collagen types I and III analysis by means of Picrosirius-red F3BA technique

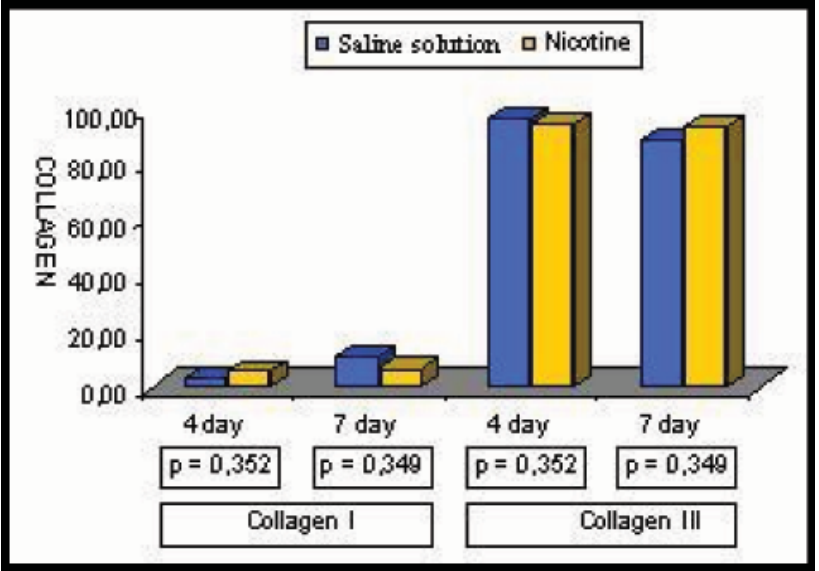

FIGURE 4 - Collagen I and Ill, in study groups

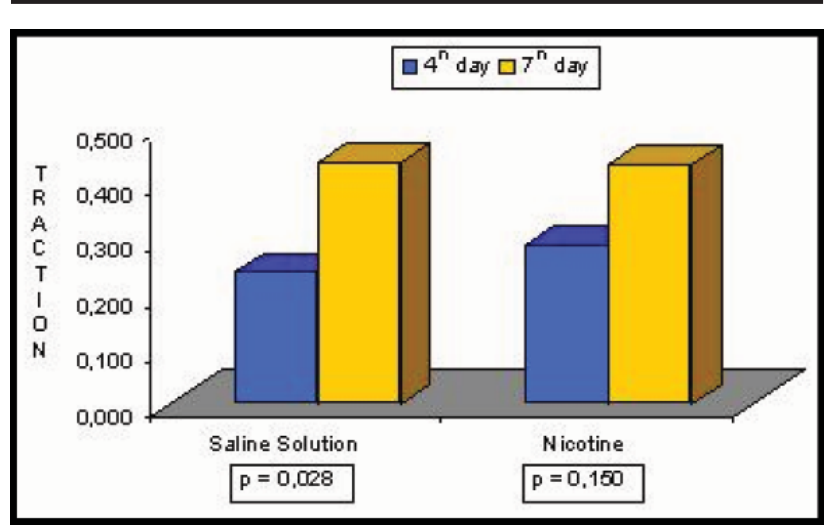

FIGURE 6 - Traction test, in the study groups

\section{Discussion}

Forrest et al. ${ }^{9}$ showed that the alterations in healing caused by the nicotine used by means of daily subcutaneous injections are time and dose dependent, and they happened after the use of the drug for 28 days prior to the surgery. Thus, in this research a subcutaneous injection of nicotine was used with a dose of $2 \mathrm{mg} / \mathrm{kg}$, so that all the animals would receive a standardized dosage in order to produce levels of nicotine similar to the levels of a chronic smoker, during a period of time of 28 days prior to the surgical procedure to observe the deleterious effects to healing. It was observed in the evaluation of the variable acute inflammatory process, by means of counting the number of neutrophils per field, a larger number of neutrophils in the physiological serum group in relation to the nicotine group on the day four, but with borderline statistic difference $(p=0.079)$, so it is 
possible that this may be a tendency. This fact may be explained through the decrease of the cell chemotaxis that may diminish the cellular presence of neutrophils to the site of the lesion. Corberand et al. ${ }^{10}$, when studied in vitro the effect of various components of the tobacco smoke on the function of polymorphonuclear cells, observed that nicotine has a deleterious effect on the motility of these cells. In the evaluation of the variable chronic inflammatory process, it was not found any significant difference in the counting of lymphocytes and plasmocytes among the samples of the two groups. However, there was an increase of plasmocytes on the day seven in the nicotine group with borderline statistic difference $(p=0.053)$. The smoke from tobacco, in similar quantities to the ones from a smoker, may produce in animals the stimulus of humoral immunity against moderate exposure and cause depression when there is prolonged exposure ${ }^{11}$. The fibroblast is the cell from the connective tissue that is responsible for the deposition of collagen in the site of lesion and the fibroplasia is already observed in an intense way on the first seven days. In the sample studied, the nicotine did not present reduction of the fibroblastic proliferation, unlike other studies that have shown an inhibitor action of the nicotine on the fibroblastic feasibility in cellular cultures ${ }^{7,12}$. Collagen supplies a structure for all the extracellular matrices and it is fundamental in the healing process. In the beginning there is a predominance of collagen type III, but it is gradually substituted by collagen type I, responsible for the tissue strength ${ }^{4}$. In this study it was not possible to observe this situation clearly and it was shown that nicotine did not influence in the deposition of collagen I and III at any moment of the study. In the evaluation of the tensile strength through the traction test there was no difference between the control and the nicotine groups at the same period of time, however in the control group there was an increment in the tensile strength from the day 4 to the $7(p=0.028)$. In the evaluation of the nicotine group, in spite of having occurred a rise in the tensile strength from the day 4 to the 7 , this rise was not significant statistically speaking. When Medeiros et al. ${ }^{8}$ evaluated the action of nicotine in the repairing of the abdominal wall of rats, they showed that nicotine decreases the strength of tension of the abdominal wall in relation to the control group, which has not been demonstrated in this study. According to Edlich et al. the bladder has great potential for repair, reaching $100 \%$ of its strength between 14 and 21 days, so the strength of bladder wound recovers quickly, unlike what happens to other organs ${ }^{13}$. The histological alterations that occur during the healing process of other organs cannot necessarily be transferred to the bladder, as a tissue may respond to the action of a substance in a different way. The action of nicotine may happen in two different ways, by direct action on the collagen or by indirect way on the components of the healing process. In this research there were inflammatory reactions due to nicotine, both from the acute inflammatory process and also the chronic one, however without statistical significance, which would represent a tendency, but that may signify an action of the drug in the immune system. In this experiment, the influence of nicotine on the fibroblastic proliferation, production of collagen and strength of tension was not observed; these factors reflect better the final result of healing. This leads to the idea that, possibly, the inflammatory alterations caused by nicotine, or its direct action, were not enough to cause structural deficiency in the healing of the vesical suture during the time of the analysis and in the conditions of the present study.

\section{Conclusion}

Nicotine, in the dose of $2 \mathrm{mg} / \mathrm{kg}$ of the animal weight, administered daily, when compared to animals from control group, showed, in the vesical suture of rabbits, a decrease in the number of neutrophils on the postoperative day four, and an increase in the number of plasmocytes on the postoperative day seven. Thus there was no difference among the groups concerning the percentage of collagen types I and III and the tissue tensile strength.

\section{References}

1. Koskimaki J, Hakama M, Huhtala H, Tammela TL. Association of smoking with lower urinary tract symptoms. J Urol. 1998;159:1580-2.

2. Reus WF, Robson MC, Zachary L, Heggers JP. Acute effects of tobacco smoking on blood flow in the cutaneous microcirculation. Br J Plast Surg. 1984;37:213-5.

3. Singer AJ, Clark RAF. Mechanism of disease: cutaneous wound healing. N Engl J Med. 1999;340:738-46.

4. Witte MB, Barbul A. General principles of wound healing. Surg Clin North Am. 1997;77:509-28.

5. Stadelmann WK, Digenis AG, Tobin GR. Impediments to wound healing. Am J Surg. 1998;176:39-47.

6. Knuutinen A, Kokkonen N, Risteli J, Vahakangas K, Kallioinen M, Salo T, Sorsa T, Oikarinen A. Smoking affects collagen synthesis and extracellular matrix turnoverinhuman skin. BrJ Dermatol.2002;146:588-94.

7. Martinez AET, Silvério KG, Rossa Júnior C. Effect of nicotine on the viability and morphology of fibroblasts: in vitro study. Pesq Odontol Bras. 2002;16:234-8.

8. Medeiros AC, Lima FP, Dantas Filho AM, Melo NMC, Azevedo IM. A nicotina atua como efeito deletério 
na reparação da parede abdominal. Acta Cir Bras. 2003;18:19-23.

9. Forrest CR, Pang CY, Lindsay WK. Dose and time effects of nicotine treatment on the capillary blood flow and viability of random-pattern skin flaps in the rat. $\mathrm{Br}$ J Plast Surg. 1987; 40:295-9.

10. Corberand J, Laharrague P, Nguyen F, Dutau G, Fontanilles M, Gleizes B, Gyrard E. In vitro effect of tobacco smoke components on the functions of normal human polymorphonuclear leukocytes. Infect Immun. 1980;30:649-55.
11. Holt PG, Keast D. Environmentally induced changes in immunological function: Acute and chronic effects of inhalation of tobacco smoke and other atmospheric contaminants in man and experimental animals. Bacteriol Rev. 1977;41:205-16.

12. Chang YC, Lii CK, Tai KW, Chou MY. Adverse effects of aerocoline and nicotine in human periodontal ligament fibroblasts in vitro. J Clin Periodontol. 2001;28:277-82.

13. Edlich RF, Rodeheaver GT, Thacker JG. Considerations in the choice of sutures for wound closure of the genitourinary tract. J Urol. 1987;137:373-9.

\section{Correspondence:}

Christiano Machado

Rua Cândido de Abreu, 660

80530-000 Curitiba - PR Brazil

christianombr@yahoo.com
Conflict of interest: none Financial source: none

Received: April 10, 2007

Review: June 12, 2007

Accepted: July 18, 2007

\section{How to cite this article}

Machado C, Chin EWK, Ioshii SO, Tâmbara Filho R, Von Bathen A. Influence of nicotine on healing of vesical sutures in rabbits. Acta Cir Bras. [serial on the Internet] 2007 Nov-Dec;22(6). Available from URL: $\underline{\text { http://www.scielo.br/acb }}$ 